\title{
IMPACT OF FISCAL AND MONETARY POLICY ON ECONOMIC GROWTH IN VIETNAM
}

\author{
Le Thanh Tung \\ Ton Duc Thang University - Faculty of Business Administration \\ No 19 Nguyen Huu Tho, Tan Phong, District 7, HCMC
}

Email:lethanhtung@tut.edu.vn

\begin{abstract}
This paper uses the Johansen cointegration test and the Vector Error Correction Model (VECM) to study the impact of fiscal and monetary policy on economy growth in Vietnam during the period from quarter I/2004 to quarter II/2013. The results showed the cointegration relation between the macroeconomic policies and economic growth. Besides, the variance decomposition and impulse response functions from VECM model showed the impact of the two policies on economic growth were limited, in which the impact of the monetary policy on growth is greater than that of the fiscal policy on growth. Subsequently, the paper provides some recommendations to improve the efficiency of the implementation of these policies in Vietnam.
\end{abstract}

Keywords: economic growth, fiscal policy, monetary policy, VECM

\section{Introduction}

On the basis of modern economics, fiscal and monetary policies are significant tools to express the government's opinions and orientation for economic growth to the economy. Fiscal policy is implemented using two main tools as tax and the government expenditure. Meanwhile, monetary policy is implemented by the government's control in money supply and even the foreign exchange rate adjustment (Gregory Mankiw, 2007). Expansionary fiscal policy is implemented on the principles of tax reduction and an increase in the government 
expenditure; however, an increase in tax and a decrease in the government's expenditure are called discretionary fiscal policy. If the government increases the money supply, it indicates that an expansionary monetary policy is implemented; meanwhile, if the money supply decreases, it means a discretionary monetary policy is performed (William and Alan, 2008).

In Vietnam, with the economic development on the basis of socialist-oriented market economy model, fiscal policy and monetary policy are tools commonly applied by the Government in order to regulate the economy. However, some questions need to be thoroughly answered:

What is the impact of fiscal and monetary policies on the GDP and economic growth of Vietnam in the past period?

$>$ Is that a positive or negative impact?

What is the separate impact of each tool ?

Thenceforth, the objectives of this study include: (i) Using quantitative tools to investigate the impact of fiscal and monetary policy tools on Vietnam economic growth in the past period, (ii) Recommending planning and administration policies to foster Vietnam economic growth in stable and sustainable way in the next period.

\section{Literature review}

In reality, the researches on the impact of fiscal and monetary policies on economic growth generate inconsistent results and even contrary. A case study for Pakistan using linear regression model by Shahid and Naved (2010) found that an expansionary fiscal policy beyond budget will result in a decrease in economic growth. Khosravi and Karimi (2010) applying ARDL model for the case of Iran during 1960-2006 period concluded that an expansionary fiscal policy may stimulate economic growth in short run and long run while there is no evidence for the relationship between economic growth and monetary policy (via the change in money supply).

In contrast, Irfan and Ume (2011) stated that the government's increase in money supply has positive relationship with economic growth. Similarly, a research by Syed et. al. (2011) for the case of Pakistan using data from 1980-2009, with an application of ECM model, showed that the government's expenditure and money supply have positive impact on 
economic growth. However, a study by Goher et. al (2011) using TSLS model showed that budget deficit (because of long-lasting expansionary fiscal policy) inhibits economic growth. A research by Musa and Asare (2012) using VECM for the case of Nigeria during the period of 1970-2010 found that money supply and the Government's expenditure have positive effect while exchange rate has negative impact on economic growth.

The previous studies showed that the impact of the policies on economic growth is mainly explained via two issues: (i) The fitness of the policy with the economy and (ii) Specific characteristics of each economy.

\section{Methodology and data description}

In order to achieve the research objectives, this paper applied Vector Error Correction Model. On basis of the research model by Khosravi and Karimi (2010) as well as Musa and Asare (2012), the impact of fiscal and monetary policies on Vietnam economic growth may be depicted by the following function:

$$
\mathrm{LGDP}_{\mathrm{t}}=\beta_{0}+\beta_{1} \mathrm{LTAX}_{\mathrm{t}}+\beta_{2} \mathrm{LGE}_{\mathrm{t}}+\beta_{3} \mathrm{LM}_{\mathrm{t}}+\beta_{4} \mathrm{LEXCH}_{\mathrm{t}}+\varepsilon_{\mathrm{t}}
$$

Where, the dependent variable LGP is the natural logarithm of gross domestic product (GDP); the independent variables such as LTAX, LGE, LM, LEXCH are the natural logarithm of tax, the Government expenditure (two tools of fiscal policy) and money supply, foreign exchange rate (two tools of monetary policy) respectively. Firstly, the variables in function (1) will be tested for unit root using Augmented Dickey-Fuller tests.

Firstly, all the variables in function (1) will be tested for unit root using two criteria of ADF (Augmented Dickey-Fuller) test.

If these variables are I(1) stationary and there exist first-order or I(1) cointegration relationship, VECM will be estimated. VECM model is constructed as follows:

First of all, we examine a VAR model with p orders, where $y$ is the vector of the variables with $\mathrm{k}=\mathrm{n}$

$$
\mathrm{y}_{\mathrm{t}}=\mathrm{A}_{1} \mathrm{y}_{\mathrm{t}-1}+\mathrm{A}_{2} \mathrm{y}_{\mathrm{t}-2}+\ldots+\mathrm{A}_{\mathrm{k}} \mathrm{y}_{\mathrm{t}-\mathrm{k}}+\mathrm{u}_{\mathrm{t}}
$$


Where, $\mathrm{y}_{\mathrm{t}}$ is a vector of non-stationary vector but $\mathrm{I}(1)$ cointegrated, and $\mathrm{A}_{\mathrm{i}}(\mathrm{n} \times \mathrm{n})$ is a matrix of estimated coefficients, $u_{t}=\left(u_{1 t}, u_{2 t}, \ldots, u_{n t}\right)$ is a matrix of residuals in the model. The function can be re-written as follows:

$$
\Delta \mathrm{y}_{\mathrm{t}}=-\prod \mathrm{y}_{\mathrm{t}-1}+\sum_{\mathrm{i}=1}^{\mathrm{n}-1} \varphi_{\mathrm{i}} \Delta \mathrm{y}_{\mathrm{t}-1}+\mathrm{u}_{\mathrm{t}}
$$

Where: $\quad \Pi=\left(\mathrm{I}-\sum_{\mathrm{i}=1}^{\mathrm{n}} \mathrm{A}_{\mathrm{i}}\right)$ and $\varphi_{\mathrm{i}}=-\left(\sum_{\mathrm{j}=\mathrm{i}+1}^{\mathrm{n}} \mathrm{A}_{\mathrm{j}}\right)=-\mathrm{A} *(\mathrm{~L})$

With an application of exogenous dummy variables or exogenous variables $\mathrm{D}, \Delta \mathrm{y}_{\mathrm{t}}$ can be presented as follows:

$$
\Delta \mathrm{y}_{\mathrm{t}}=\prod \mathrm{y}_{\mathrm{t}-1}+\Gamma_{1} \Delta \mathrm{y}_{\mathrm{t}-1}+\varphi \mathrm{D}_{\mathrm{t}}+\mathrm{u}_{\mathrm{t}}
$$

The multinomial in $\Delta \mathrm{y}_{\mathrm{t}}$ :

$\Pi(\lambda)=\mathrm{I}_{\mathrm{p}}-\lambda \Pi_{1}-\lambda^{2} \Pi_{2}=(1-\lambda) \mathrm{I}_{\mathrm{p}}-\Pi \lambda-\Gamma_{1} \lambda(1-\lambda)$ has unit root, then $|\Pi(\lambda)|=0$ at $\lambda=1$ and $\Pi(1)=-\Pi=-\alpha \beta$. Finally, VECM model is written as follows:

$$
\Delta \mathrm{y}_{\mathrm{t}}=\alpha \beta^{\prime} \mathrm{y}_{\mathrm{t}-1}+\Gamma_{1} \Delta \mathrm{y}_{\mathrm{t}-1}+\varphi \mathrm{D}_{\mathrm{t}}+\mathrm{u}_{\mathrm{t}}
$$

Before the estimation of VECM model, testing for cointegration relationship among variables in the model was conducted using Johansen and Juselius test. Moreover, a lag selection for VECM model was based on AIC (Akaike Information Criterion) and SBC (Schwarz Bayesia Information Criterion). Finally, the measurement of the impact of fiscal and monetary policy on economic growth was investigated by Variance Decomposition analysis of Impulse response functions (IRF).

In order to implement the research objectives, the research applied the quarterly data from quarter I/2004 to quarter II/2013, with the number of observations $n=38$. All the data in this research (except exchange rate) are adjusted to price of the base year 1994. Gross domestic product (GDP) data are from Vietnam General Statistics Office (GSO); Tax and Government expenditure (GE) data are from the Vietnam Ministry of Finance; money supply (M) data are from State Bank of Vietnam. Exchange rate $(\mathrm{EXCH})$ data are nominal exchange rate between Vietnam Dong and US dollar from the State Bank of Vietnam. Data of the 
above-mentioned variables are converted into natural logarithm form when putting into VECM model.

\section{Research result}

In order to conduct unit root test for the variables in VECM, this study employed ADF (Augmented Dickey-Fuller) test. The testing results from Table 1 showed that only LGE is $\mathrm{I}(0)$ stationary series (significant at 1 percent) while the remaining variables are nonstationary.

The result from table 1 indicated that only LGE is $\mathrm{I}(0)$ stationary series at $1 \%$ significant level while the remaining variables are non-stationary. However, testing for first order difference showed that these variables are first order I(1) stationary series at $1 \%$ significant level. This implied that if the first-order cointegration relationship among the variables exists in the model, VECM will be constructed using first order difference I(1) series.

\section{TABLE 1: Results of Unit Root Test}

\begin{tabular}{|l|c|c|}
\hline \multirow{2}{*}{\multicolumn{1}{|c|}{ Variable }} & \multicolumn{2}{|c|}{ ADF Criteria } \\
\cline { 2 - 3 } & $\mathbf{I}(\mathbf{0})$ & $\mathbf{I}(\mathbf{1})$ \\
\hline LGDP & 0,045775 & $-2,938063 * * *$ \\
\hline LTAX & $-1,680730$ & $-3,996594 * * *$ \\
\hline LGE & $-5,654529 * * *$ & $-5,289334 * * *$ \\
\hline LM & $-2,022853$ & $-8,881039 * * *$ \\
\hline LEXCH & 0,760485 & $-5,428546 * * *$ \\
\hline
\end{tabular}

Note: $* * *, * * *$ Stationary with significant level at $1 \%, 5 \%, 10 \%$

Source: Calculated from research data

After unit root test, Johansen and Juselius (1990) tests are also employed to test for long-run cointegration relationship among the variables in VECM. The results from table 2 showed that the hypothesis of no cointegration vector is rejected at 5\% significant level. Trace test confirmed that there exists at most 2 vectors and Max-Eigenvalue test also confirmed the existence of at most 01 cointegration vector among the variables at 5\% 
significant level. The testing results indicated that the variables are first-order stationary and there exists the cointegration relationship; therefore, it is qualified for VECM estimation in the next part.

TABLE 2: Results of Johansen's Cointegration tests

\begin{tabular}{|c|c|c|c|c|}
\hline \multicolumn{5}{|c|}{ Series: LGDP LTAX LGE LM LEXCH } \\
\hline \multicolumn{5}{|c|}{ Johansen Trace Test } \\
\hline $\begin{array}{l}\text { Hypothesized } \\
\text { No. of CE(s) }\end{array}$ & Eigenvalue & $\begin{array}{l}\text { Trace } \\
\text { Statistic }\end{array}$ & $\begin{array}{c}\text { Critical value } \\
0,05\end{array}$ & Probability ** \\
\hline None $*$ & 0,643892 & 90,14261 & 69,81889 & 0,0005 \\
\hline At most $1 *$ & 0,529140 & 52,97181 & 47,85613 & 0,0153 \\
\hline At most 2 & 0,419082 & 25,85677 & 29,79707 & 0,1331 \\
\hline At most 3 & 0,154720 & 6,303515 & 15,49471 & 0,6597 \\
\hline At most 4 & 0,006986 & 0,252366 & 3,841466 & 0,6154 \\
\hline \multicolumn{5}{|c|}{ Trace test indicates 2 cointegrating eqn(s) at the 0.05 level } \\
\hline \multicolumn{5}{|c|}{ Johansen Maximum Eigenvalue Test } \\
\hline $\begin{array}{l}\text { Hypothesized } \\
\text { No. of } \mathrm{CE}(\mathrm{s})\end{array}$ & Eigenvalue & $\begin{array}{c}\text { Max-Eigen } \\
\text { Statistic }\end{array}$ & $\begin{array}{c}\text { Critical value } \\
0,01\end{array}$ & Probability $* *$ \\
\hline None $*$ & 0,643892 & 37,17080 & 33,87687 & 0,0195 \\
\hline At most 1 & 0,529140 & 27,11504 & 27,58434 & 0,0573 \\
\hline At most 2 & 0,419082 & 19,55326 & 21,13162 & 0,0819 \\
\hline At most 3 & 0,154720 & 6,051149 & 14,26460 & 0,6067 \\
\hline At most 4 & 0,006986 & 0,252366 & 3,841466 & 0,6154 \\
\hline
\end{tabular}

Source: Calculated from research data

The determination of lag length for a VECM is based on a comparison between AIC and SBC from regression process for VECM with various lags. Finally, we select lag=2 as an optimal lag length for VECM with the variables in function (1). The regression results for VECM with 2 lags are presented in table 3: 
TABLE 3: Estimated Results of VECM

\begin{tabular}{|c|c|c|c|c|c|}
\hline \multicolumn{6}{|c|}{ Sample (Adjusted): 438} \\
\hline Cointegrating Eq: & \multicolumn{5}{|l|}{ CointEq1 } \\
\hline LGDP(-1) & \multicolumn{5}{|l|}{1,000000} \\
\hline $\operatorname{LTAX}(-1)$ & \multicolumn{5}{|l|}{0,14280} \\
\hline LGE(-1) & \multicolumn{5}{|l|}{$-0,016769$} \\
\hline $\mathrm{LM}(-1)$ & \multicolumn{5}{|l|}{$-0,531113$} \\
\hline LEXCH(-1) & \multicolumn{5}{|l|}{$-0,461971$} \\
\hline $\mathrm{C}$ & \multicolumn{5}{|l|}{1,606041} \\
\hline Error Correction: & $\mathrm{D}($ LGDP) & $\mathrm{D}(\mathrm{LTAX})$ & $\mathrm{D}(\mathrm{LGE})$ & $\mathrm{D}(\mathrm{LM} 2)$ & $\mathrm{D}(\mathrm{LEXCH})$ \\
\hline CointEq1 & $-2,502438$ & $-3,822600$ & $-3,114814$ & $-1,344468$ & $-0,050779$ \\
\hline DLGDP(-1) & 1,049382 & 2,402534 & 3,349522 & 0,714568 & $-0,005414$ \\
\hline DLGDP(-2) & 0,637549 & 1,382064 & 1,254033 & 0,493524 & $-0,017173$ \\
\hline DLTAX(-1) & 0,497605 & 1,029610 & 0,461917 & 0,675934 & 0,041563 \\
\hline DLTAX(-2) & 0,188673 & 0,297018 & 0,591717 & 0,090452 & 0,038608 \\
\hline DLGE(-1) & $-0,037841$ & $-0,069836$ & $-1,033541$ & $-0,055339$ & 0,003815 \\
\hline DLGE(-2) & $-0,038882$ & $-0,013035$ & $-0,576055$ & $-0,016694$ & 0,005145 \\
\hline $\operatorname{DLM}(-1)$ & $-0,811906$ & $-1,692823$ & 0,076561 & $-1,150201$ & $-0,026177$ \\
\hline $\operatorname{DLM}(-2)$ & $-0,305789$ & $-0,933120$ & 0,014591 & $-0,589048$ & $-0,027511$ \\
\hline DLEXCH(-1) & $-0,001097$ & $-2,368025$ & $-3,788375$ & $-2,313101$ & 0,000386 \\
\hline DLEXCH(-2) & 0,189812 & $-2,206716$ & 1,441378 & $-0,577168$ & 0,033214 \\
\hline $\mathrm{C}$ & 0,022718 & 0,071399 & $-0,010484$ & 0,098538 & 0,009052 \\
\hline $\mathrm{R}^{2}$ & 0,947054 & 0,825447 & 0,592846 & 0,517125 & 0,264011 \\
\hline Adjusted $\mathrm{R}^{2}$ & 0,921732 & 0,741965 & 0,398120 & 0,286185 & $-0,087984$ \\
\hline
\end{tabular}

Source: Calculated from research data

After conducting Variance Decomposition, the estimated result of function (1) VECM with two lags showed that the tools of fiscal and monetary policy have impact on economic 
growth. ANOVA results (Table 4) showed that the change in GDP is $74.1 \%$ in short run and declines to $62.2 \%$ in long term, the variation of tax is $3.7 \%$ in short term and increases to $4.2 \%$ in long term,; the Government budget expenditure changes $2.2 \%$ in short term and increases to $5.7 \%$ in long term, the short-run change of money supply is $16.7 \%$ and in long run is $23.2 \%$, exchange rate changes $3.14 \%$ in short term and increases up to $4.5 \%$ in long term.

The results from Variance Decomposition showed that the tools of monetary policy cause 19.8 percent of the change of GDP in short term and 27.7 percent in long term; however, the tools of fiscal policy only resulted in 5.9 percent of the change in GDP in short term and 9.9 percent of the variation in GDP in long term. Therefore, it could be concluded that monetary policy has more remarkable impact on GDP than fiscal policy in the period of the research. In summary, the combination of these two policies resulted in 25.8 percent of variation in GDP in short run and 37.7 percent in long run.

TABLE 4: ANOVA Result

\begin{tabular}{|c|c|c|c|c|c|c|}
\hline \multicolumn{6}{|c|}{ Variance Decomposition of LGDP } \\
\hline Period & S.E. & LGDP & LTAX & LGE & LM & LEXCH \\
\hline 1 & 0,073795 & 100,0000 & 0,000000 & 0,000000 & 0,000000 & 0,000000 \\
\hline 2 & 0,091677 & 74,11840 & 3,759693 & 2,254428 & 16,72250 & 3,144983 \\
\hline 3 & 0,097913 & 65,92962 & 3,838928 & 2,411089 & 24,88938 & 2,930983 \\
\hline 4 & 0,100630 & 62,54437 & 5,299166 & 3,937977 & 24,76645 & 3,452041 \\
\hline 5 & 0,122243 & 72,25455 & 4,161925 & 3,992244 & 17,25138 & 2,339907 \\
\hline 6 & 0,130962 & 65,29109 & 4,218568 & 5,469337 & 20,79543 & 4,225576 \\
\hline 7 & 0,135833 & 61,42808 & 4,220729 & 5,355313 & 25,02505 & 3,970824 \\
\hline 8 & 0,137718 & 60,10034 & 4,670871 & 5,656551 & 25,29715 & 4,275085 \\
\hline 9 & 0,150580 & 65,97103 & 4,157567 & 5,011915 & 21,28130 & 3,578185 \\
\hline 10 & 0,155868 & 62,27665 & 4,199313 & 5,728547 & 23,28355 & 4,511939 \\
\hline
\end{tabular}

Source: Calculated from research data 
In the next part, the impact of fiscal and monetary policies on economic growth in Vietnam in research period will be analyzed using impulse response functions (IRF). The results from IRF analysis will modify the afore-mentioned ANOVA results. The duration used for IRF analysis is 10 quarters (2.5 years).

\section{FIGURE 1: Response Functions of the Variables from Policy Shocks}
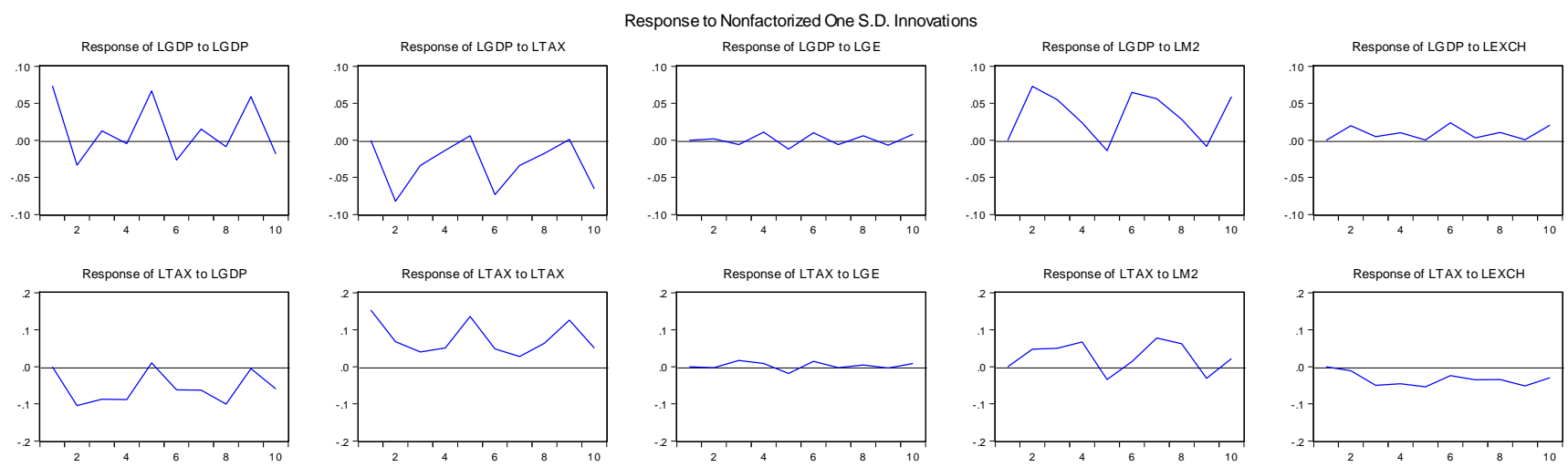

Response of LTAX to LEXCH
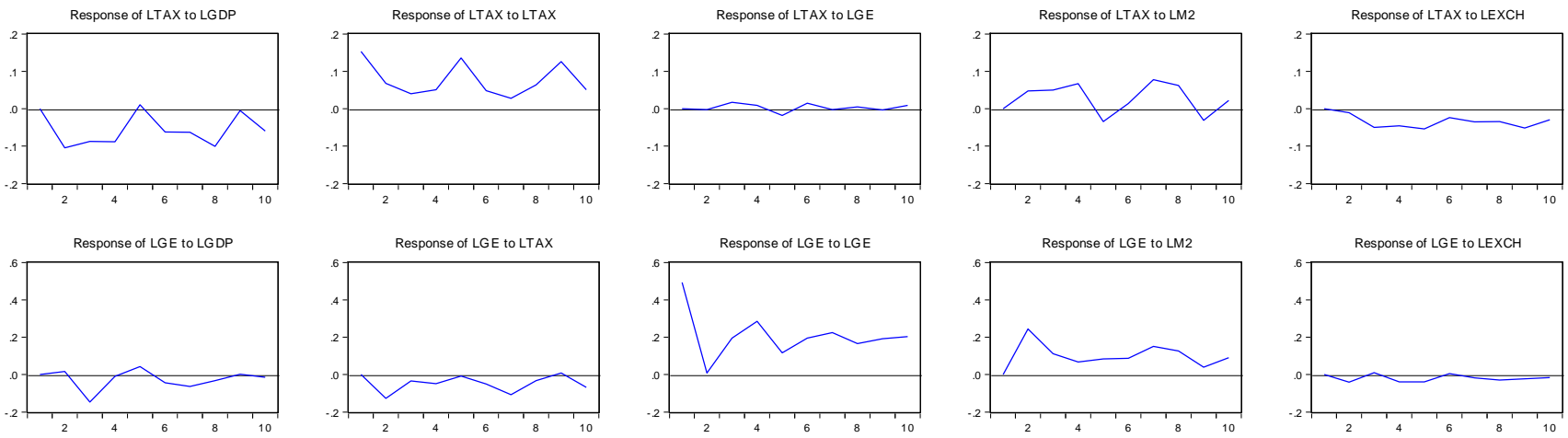

Response of LM2 to LGDP
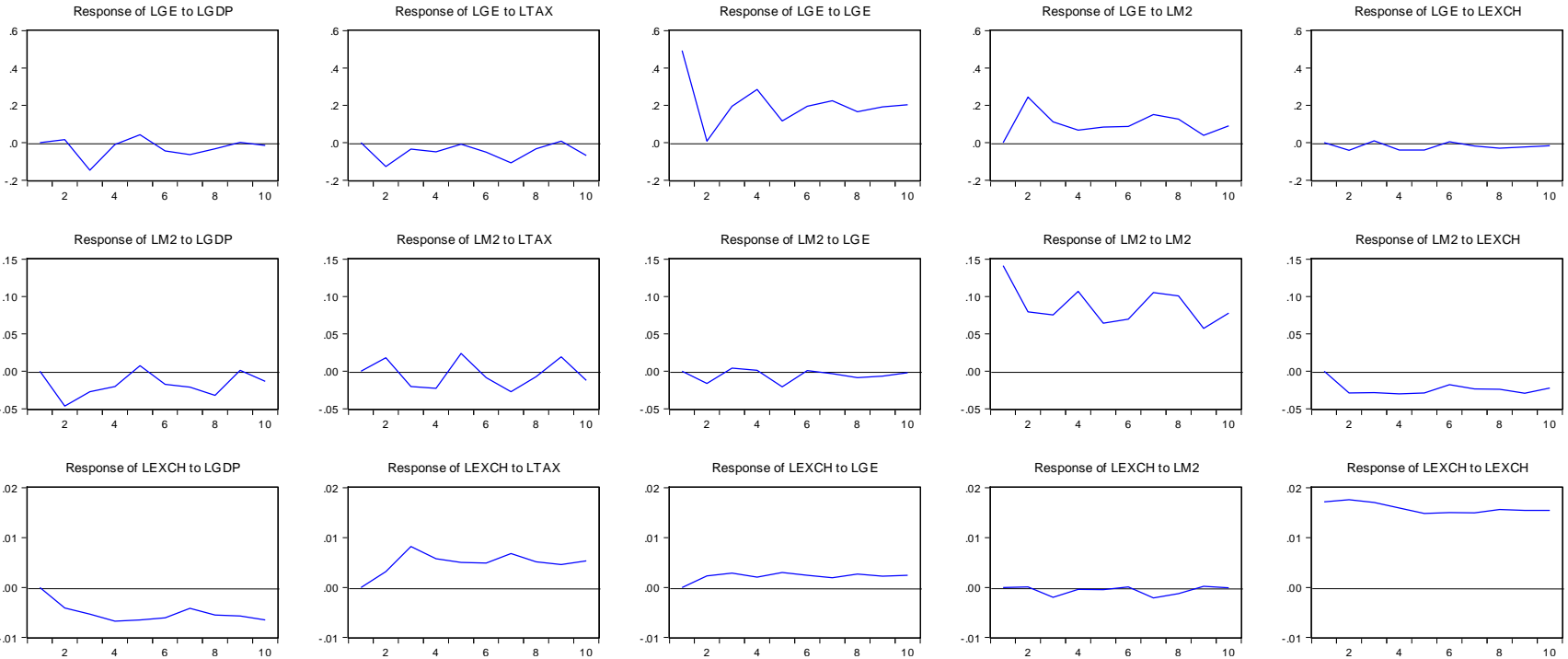

Source: Calculated from research data

IRF analysis (Line 1 Fig 1) indicated the impact of tools of the policies as follows: (i) tax tool (Fig. Response of LGDP to LTAX) inhibited economic growth during these period, an increase in tax resulted in a decrease in growth rate; (ii) Government expenditure (Fig. Response of LGDP to LGE) resulted in up-and-down fluctuation of GDP, but this variation in GDP is rather small, which indicates the effectiveness of Government expenditure in the research period is limited; (iii) money supply (Fig. Response of LGDP to LM) has remarkable impact on economic growth, an increase in money supply will stimulate the growth rate up to 
optimal level after two quarters, but a decrease in money supply (discretionary monetary policy) causes a dramatic decline in economic growth; iv) exchange rate tool (Fig. Response of LGDP to LEXCH) has positive effect on economic growth, but this impact is not remarkable, which indicates change rate is not primary tool for stimulating economic growth in the past period.

Moreover, on the basis of IRF, it can be indicated that all the primary tools of fiscal and monetary policies contribute to the up-and-down fluctuation (positive and negative impact) in GDP in the research period. It implied that in addition to macro adjustment, the tools of fiscal and monetary policies are one of the factors that result in the fluctuation of economic growth during the past time.

\section{Conclusion and policy implications}

With an application of VECM to evaluate the impact of fiscal and monetary policy on Vietnam's economic growth from quarter I/2004 to quarter II/2013, the results are as follows: (1) Monetary policy (specifically money supply tool) has more significant impact than tools of fiscal policy; (2) The outstanding impact of money supply in comparison with that of other tools of both policies showed that Vietnam's economic growth in the research period relies much on the increase of money supply, namely a decrease in money supply will lead to a decline in economic growth; (3) the tools of both policies also contribute to the fluctuation in GDP (that is, the change in economic growth rate) in the research period.

With the objective of increasing the effectiveness in policy planning and policy administration and improving the stability and sustainability of Vietnam's economic growth, the Government need to concentrate on the following issues:

Firstly: It is necessary to establish the mechanism for comprehensive co-ordination, exchanging, information response as well as to promote positive impact of application of policy mix. The results showed that tax and money supply tools, in some certain periods, have negative impact on the output. This indicated that the tools themselves reduce their effectiveness and the efficiency of the policy. Moreover, it is necessary to create a transparent direction of policy administration in medium and long term. It should be noted that the longterm consistency needs to be ensured in order for the effective promotion of the policies. 
Secondly: ANOVA results showed that the impact of the two policies on economic growth is not remarkable. It seemed that the main motivation of Vietnam economic growth does not result from these important policies but from other economic activities. Moreover, the research result showed that these policies are the factors that cause the fluctuation in GDP. Therefore, in the coming time, it is necessary not to implement policies that may cause "shock" to the national economy such as stimulus policy at the beginning of 2009 or rapid money supply policy in the period of 2006-2007.

Thirdly: From the results of ANOVA and response function, it was shown that monetary (especially money supply) has played a significant role in economic growth. In reality, from 2010-2012, monetary policy was planned and administrated aiming at inflation stabilization, exchange rate stabilization, financial market and gold market adjustment, etc...rather than economic growth. Thenceforth, it resulted in a reduction in Vietnam economic growth to a lowest rate in the last two decades. Moreover, the fact that although interest rate has decreased dramatically from 2012 up to now, the investment and economic growth rate still increase slowly indicating that the effectiveness of the policy is not high. Therefore, in the next period, it is necessary to increase the efficiency of monetary policy via unblocking the transmission channels such as bank network, financial market, capital market, etc...

Fourthly: The research results showed that tax tool has obvious impact on inhibiting the economic growth. In reality, from 2006 to 2010, the ratio of tax/GDP in Vietnam was 26.2 percent, which is higher than that of other countries in the Southeast Asia (Ministry of Finance, 2012). Therefore, in the coming time, in order to promote economic growth in Vietnam, there will be a need of a route of tax reduction (This study found that tax reduction contributes to Vietnam economic growth in both short and long term).

Fifthly: The research found the impact of exchange rate on economic growth was not remarkable, which means the Government need to continue stabilizing exchange rate as it was from the beginning of 2012 up to now in order to prevent the economy from "supply shock" due to an increase in price of production inputs which results in an increase in inflation rate, macro instability and negative impact on economic growth. 


\section{Reference}

1. Anvar Khosravi and Mohammad Sharif Karimi (2010), "To Investigation the relationship between monetary, fiscal policy and economic growth in Iran: Autoregressive Distributed Lag Approach to cointegration”, American Journal of Applied Sciences, No 7 (3), PP 415 -419 .

2. Goher Fatima, Ather Maqsood Ahmed and Wali Ur Rehman (2011), "Fiscal deficit and economic growth: An analysis of Pakistan's economy", International Journal of Trade, Economics and Finance, Vol 2, No 6, 501-504.

3. Irfan Hameed and Ume Amen (2011), "Impact of monetary policy on gross domestic product", Interdisciplinary Journal of Contemporary Research in Business", Vol 3, No 1, PP 1348-1361.

4. Johansen, Soren and Katarina Juselius (1990), "Maximum Likelihood estimation and inferences on cointegration - with applications to the demand for money", Oxford Bulletin of Economics and Statistics, No 52, PP 169-210.

5. Musa Y. and Asare B. K. (2012), "Long and Short run relationship analysis of monetary and fiscal policy on Economic growth in Nigeria: A Vec model approach", Research Journal of Applied Science, Engineering and Technology, Vol 5, No 10, PP 3044-3051.

6. Gregory Mankiw (2007), Principles of macroeconomics (4 ${ }^{\text {th }}$-edition), Thomson SouthWestern, USA.

7. Shahid Ali and Naved Ahmad (2010), "The effects of fiscal policy on economic growth: Empirical evidences based on times series data from Pakistan", The Pakistan Development Review, 49:4 Part II (Winter 2010), PP 497-512.

8. Syed Tehseen Jawaid, Faisal Sultan Qadri, Nasir Ali (2011), "Monetary-Fiscal-Trade policy and Economic growth in Pakistan: Time series Empirical Investigation", International Journal of Economics and Financial Issues, Vol 1, No 3, PP 133-138.

9. Uy ban Ngan sach Tai chinh Quoc hoi-UNDP (2012), Ky yeu Hoi thao quoc te-Cac giai phap đoi moi chinh sach tai khoa vói viec tai co cau nen kinh te, Ha Noi, Vietnam. 
10. Uy ban Kinh te Quoc hoi-UNDP-Vien Khoa hoc Xa hoi Viet Nam (2011), Ky yeu Hoi thao kinh te Viet Nam: Nhung van đe đat ra trong trung va dai han, Can Tho, Vietnam.

11.William J. Baumol, and Alan S. Blinder (2008), Macroeconomics Principles and Policy, Thomson South-Western, USA. 